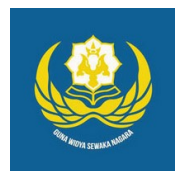

Jurnal Analogi Hukum

Journal Homepage: https://ejournal.warmadewa.ac.id/index.php/analogihukum

\title{
Tanggung Jawab Maskapai Penerbangan Terhadap Eksistensi Penumpang
}

\author{
I Komang Gede Indra Dwipayana*, Luh Putu Sudini dan Desak Gede Dwi Arini
}

Fakultas Hukum, Universitas Warmadewa, Denpasar, Bali-Indonesia

*dwipayana@gmail.com

\begin{abstract}
How To Cite:
Dwipayana, I, K, G, I., Sudini, L, P., Arini, D, G, D. (2020). Tanggung Jawab Maskapai Penerbangan Terhadap Eksistensi Penumpang. Jurnal Analogi Hukum. 2(1). 68-72. Doi: http://dx.doi.org/10.22225/.2.1.1621.68-72
\end{abstract}

\begin{abstract}
Research on Airline Responsibility for Passenger Safety is based on the fact that there are still many airlines if the plane crashes and does not fully compensate insurance that must be replaced with their passengers.There are passengers who until his death were in fact not being repaid and was considered a breakup when they can be replaced by their heirs. Based on this, this study raises the problem formulation of the duties and authority of the airline for the existence of passengers as well as what compensation and how much compensation should be paid by the airline for the existence of passengers. his type of research used in this study is a type of normative legal research using the legislation approach by examining all laws relating to the writing of airline responsibilities for passenger safety and conceptual approaches by combining the opinions of experts so that it becomes an author's argument. The results of this research show that the tasks and authorities of the airlines is to start from the beginning to leave the waiting room, entered the plane to come down in the destination airport, passengers must safely without any deficiencies in addition, compensation the airline is set in law number 1 Year 2009 about aviation and Transport Minister Regulation Number 77 Year 2011 about the type of Responsibility of the carrier. In the Ministerial Regulation explains that passengers who have experienced accident entitled awarded damages by the airlines maximum is Rp. 1.250.000.000 (one billion two hundred and fifty million rupiah).
\end{abstract}

Keywords: Responsibility, the Airline, the Safety

Abstrak-Penelitian tentang Tanggung Jawab Maskapai Penerbangan Terhadap Keselamatan Penumpang didasari karena masih banyaknya maskapai penerbangan jika pesawatnya mengalami kecelakaan tidak mengganti rugi secara penuh asuransi yang harus digantikan kepada penumpang mereka. Ada penumpang yang sampai meninggal dunia namun tidak dilunasi dan dianggap putus hubungan padahal bisa digantikan oleh pewarisnya. Berdasarkan hal tersebut maka penelitian ini mengangkat rumusan masalah apa saja tugas dan kewenangan maskapai penerbangan terhadap eksistensi penumpang serta ganti rugi apa yang dan berapa jumlah ganti rugi yang seharusnya dibayarkan oleh maskapai penerbangan terhadap eksistensi penumpang. Jenis penelitian yang digunakan dalam penelitian ini adalah jenis penilitian hukum normatif dengan menggunakan pendekatan perundang-undangan dengan menelaah semua Undang-undang yang berhubungan dengan penulisan tanggung jawab maskapai penerbangan terhadap keselamatan penumpang serta pendekatan konseptual dengan menggabungkan pendapat para ahli sehingga menjadi suatu argumentasi penulis. Hasil penelitian ini menunjukan bahwa tugas dan kewenangan maskapai penerbangan adalah mulai dari awal meninggalkan ruang tunggu, masuk pesawat hingga turun di bandar udara tujuan penumpang harus dengan selamat tanpa ada kekurangan apapun selain itu ganti rugi maskapai penerbangan diatur di dalam UndangUndang Nomor 1 Tahun 2009 tentang Penerbangan dan Peraturan Menteri Perhubungan Nomor 77 Tahun 2011 tentang Jenis Tanggung Jawab Pengangkut. Di dalam peraturan menteri ini menjelaskan bahwa penumpang yang mengalami kecelakan berhak diberikan ganti rugi oleh pihak maskapai penerbangan maksimal sebesar Rp.1.250.000.000 (satu miliar dua ratus lima puluh juta rupiah).

Kata Kunci: Tanggung Jawab, Maskapai,Keselamatan

1. Pendahuluan

Pengangkutan udara amat efisien dipakai untuk muatan jaraknya jauh. Ini disebabkan laju dan kapasitas capaiannya cukup singkat dan nyaris di setiap daerah yang mempunyai tempat 
lapangan terbang walaupun dalam bentuk sarana yang sederhana, juga masih dapat ditempati dengan pesawat terbang ringan. Daerah-daerah kecil yang sulit dicapai menggunakan sarana transportasi lain, pengangkutan udara sangat diperlukan meskipun jika dilihat dari segi pembiayaan cukup tinggi dan kurang efisien (Purwosutjipto, 1983). Namun, dewasa ini banyak kecelakaan yang terjadi dengan pesawat dan di Indonesia sudah sering terjadi 10 tahun belakangan sehingga pada saat suatu waktu dimana jumlah kecelakaan pesawat itu bisa berlangsung dua sampai tiga kali didalam satu tahun. Kejadian seperti ini amat mengkhawatirkan masyarakat bahwa separuh masyarakat di Indonesia menunjuk alur transportasi udara untuk opsi angkutan mereka untuk alasan efisien waktu dan tidak menghabiskan banyak waktu untuk destinasi keluar kota maupun keluar negeri

Pada hakikatnya keselamatan transportasi ialah hak setiap masyarakat negara, maka pemerintah Indonesia harus merealisasikan dan memproteksi pengadaan transportasi yang safe, tidak berantakan, tidak macet macetan, dan dapat dijangkau. Penumpang yang diangkut harus dapat asuransi keselamatan bersama barang bawannya ataudiangkut dan diterima di Bandar udara tertuju dengan keadaan awal pada saat datangdi Bandar udara muatan. Yang termasuk unsur-unsur dalam system transportasi ada beberapa, yaitu:

Menjalankan obyek yang diterima baik itu manusia, binatang ataupun barang-barang

\section{Memproteksi obyek yang diangkut}

Mengemudikan laju dana dri gerak, sampai keamanan selama berada di jalan bisaterjamin (Setijowarno \& Frazila, 2001).

Pelayanan transportasi dengan jaminan selamat pasti memberi rasa pasti dan tenang bagi penumpang atau bagi sipemilik barang, maka kegiatan social ekonomi warga bisa terproteksi. Jika, keselamatan transportasi terpercaya, dan hak warga pemakai terjamin, maka tidakakan bermunculan biaya-biaya yang tidak seharusnya perlu dan kontra produktif (Alim, 1994).

Ketentuan Pasal 1 angka 48 pada UndangUndang Republik Indonesia Nomor 1 Tahun 2009 Tentang Penerbangan menegaskan:

Keselamatan Penerbangn ialah kondisi terpenuhinya syarat dalam keamanan, kemanfaatan wilayah udara, pesawat, bandara, pengangkutan udara, pelayanan penerbangan, hingga fasiilitas yang menujang dan fasilitas umum lain-lainnya.

Sedangkan Menurut pasal 1 ayat (3) Peraturan Menteri Perhubungan Nomor 77 Tahun 2011 Tentang Tanggung Jawab Pengangkut Angkutan Udara, definisi tanggungjawab angkutan ialah

Tanggungjawab dari perusahaaan maskapai udara untuk mengganti rugi yang telah dialami oleh penumpang yang mengirim barang dan pihak ketiga.

Dari uraian latar belakang diatas, maka penulis tertarik untuk melakukan penelitian dan menulis skripsi yang berjudul Tanggung Jawab Maskapai Penerbangan Terhadap Keselamatan Penumpang.

Adapun sesuai dari uraian latar belakang diatas, dapat dirumuskan masalah yaitu: Bagaimana tugas dan kewenangan maskapai penerbangan terhadap eksistensi penumpang?, Bagaimana ganti rugi maskapai penerbangan terhadap eksistensi penumpang?

\section{Metode}

Dalam metode ini penulis menggunakan metode yuridis normatif, Untuk lebih jelasnya dapat dipaparkan sebagai berikut:

Tipe Penelitian dan Pendekatan Masalah

Dalam penulisan ini penulis menggunakan tipe penelitian hukum normative dengan memakaitipependekatan Perundang-undangan dan tipe pendekatan Konseptual. Tipe Pendekatan Perundang-undangan ialah dengan menganalisis semua undang-undang yang bersangkutan dengan tanggung jawab maskapai penerbangan terhadap eksistensi penumpang dan pendekatan konseptual adalah dengan mengumpulkan pendapat para ahli dan meringkasnya sehingga menjadi argumentasi penulis.

\section{Sumber Bahan Hukum}

Sumber bahan hukum yang digunakan adalah Undang-Undang Dasar Negara Republik Indonesia Tahun 1945, Undang-Undang Republik Indonesia Nomor 1 Tahun 2009 Tentang Penerbangan, Peraturan Menteri Perhubungan Nomor 77 Tahun 2011 Tentang Tanggung Jawab Pengangkut Angkutan Udara.

\section{Analisis Data}

Analisis data dalam penulisan ini menggunakan kualitatif-deskriptif, yaitu dengan mendiskripsikan bahan hukum terlebih dahulu secara sistematis kemudian 
menganalisa melalui teknik analisis dengan teknik tafsiran dan menggunakan argumentasi yang bertumpuk pada logika hukum dengan deduktif-induktif.

\section{Hasil Penelitian Dan Pembahasan}

\section{Tugas dan Kewajiban Maskapai Penerbangan Terhadap Eksistensi Penumpang}

Di hampir setiap pengadaan pengangkutan udara pasti mempunyai resiko rugi besar karena diakibatkan oleh kecelakaan yang selanjutnya memiliki dampak pda konsekuensi hukum. Resiko ini khususnya yang berhubungan dgn pemberian santun kerugian kepada pemakai jasa maskapai udara yang menderita kerugian untuk sebuah bentuk tanggung jawab hukum (legal liability) dari perusahaan maskapai (Martono, 2007).

Jenis tanggung jawab maskapai penerbang bagi penumpang diatur didalam Peraturan Menteri Perhubungan Nomor 77 Tahun 2011 $\mathrm{Bab}$ II tentang macam pertanggungjawaban angkutan udara dan jumlah ganti rugi pasal 2 yang mengatakan pengangkut yang menggunakan pesawat udara harus bertanggungjawab atas rugi terhadap:

Penumpang meninggal, cacat permanen atau luka-luka; Hilang dan rusak bagasi cabin; Musnah, atau hancur bagasi tercatat; Musnah, atau rusak cargo; Angkutan udara delay,dan

Rugi yang diderita diderita oleh pihak ketiga.Oleh karena itu tanggung jawab maskapai udara dalam hal ini maskapai penerbangan yaitu mulai naik sampai turunnya penumpang pesawat udara.

Limit pertanggungjawaban perusahaan maskapai ada didalam Peraturan Menteri Nomor 77 tahun 2011 Tentang Tanggung Jawab Maskapai Penerbangan yaitu pada

\section{Pasal 18}

Pertanggungjawaban maskapai terhadap penumpang diawali dari penumpang melewatkan ruang tunggu bandara ke pesawat hingga sampai penumpang masuk terminal kedatangan dibandara tujuan.

Pertanggungjawaban maskapai pada bagasi mulai dari maskapai telah menerima bagasi pada waktu pelaporan (check-in) sampai penumpang menerima begasi.

Pertanggungjawaban maskapai terhadap cargo diawali dari yang mengirim barang mendapat salinan surat muatan udara dari yang mengangkut pengangkut sampai hingga waktu yang ditentukan sebagai batas diambilnya sesuai dengan yang ada didalam surat muatan udara (airway bill).

Pertanggungjawaban terhadap penumpang yang wajib dijalankan oleh perusahaan maskapai yang jelas diatur pada UndangUndang Republik Indonesia Nomor 1 Tahun 2009 Tentang Penerbangan dan diatur lebih khusus lagi dalam Peraturan Menteri Nomor 77 Tahun 2011 tentang tanggung jawab pengangkut angkutan udara. Pada peraturan tersebut menyebutkan bahwa tanggung jawab perusahaan penerbangan terhadap penumpang wajib dilaksanakan sebagai syarat untuk menjalankan pengangkutan udara. Pada peraturan tersebut juga disebutkan batas-batas tanggung jawab pengangkut, wajib asuransi tanggung jawab pengangkut, syarat dan tata cara pengajuan ganti rugi dan nominal yang harus dibayarkan jika penumpang mengalami kecelakaan dan sebagainya.

\section{Ganti Rugi Maskapai Penerbangan Terhadap Eksistensi Penumpang}

Kesepakatan asuransi berisi prinsip bahwasannya yang ditanggung akan memperoleh ganti kerugian klaim dari penanggung maksimal sebesar kerugian yang diderita, pertanggungjawaban yang secara hukum harus dibayakan atau hilangnya pemasukan yang diharap. Pada asuransi umum atau kemalangan, pertanggungaan asuransi dimaksud untuk memberi ganti rugi yang bisa mengcover orang yang ditanggung secara finansial tidak lebih menguntungkan dikarena timbul suatu hal yang dijaminkan didalam kesepakatan asuransi yang dipunyai didalam pengasuransian, ganti rugi adalah tujuan bahwasan asuransi adalah pengalihan resiko. Mengalihkan resiko yang mungkinbisaterjadi atau dijalani oleh yang ditanggungg dari suatu kejadian yang tidak harapkan dan belum tentu akan terjadi

Adapun sesuai Pasal 3 Peraturan Menteri Perhubungan nomor 77 Tentang Tanggung Jawab Pengangkut Angkutan Udara ialah:

Pesawat udara yang mengalami kecelakaan atau peristiwa yang sebatas memiliki hubungan dengan maskapaipenerbangan dibayarkan kerugian sebesar Rp. 1.250.000.000,00 (satu miliar dua ratus lima puluh juta rupiah) per penumpang

Bagi penumpang yang sampai meninggal dunia akibat suatu peristiwa yang sebatas 
berada diruang tunggu bandara akan ke pesawat atau pada saat proses turun dari pesawat ke ruang kedatangan bandara tertuju atau bandara transit diberi santunan senilair Rp. 500.000.000,00 (lima ratus juta rupiah) per penumpang;

Bagi para penumpang yang mengalami cacat permanen, seperti

Penumpang yang divonis cacat permanen total oleh dokter masih didalam jangka waktu 60 (enam puluh) hari kerja semenjak terjadi kecelakaan diberikan santunan senilai Rp.1.250.000.000,00 (satu miliar dua ratus lima puluh juta rupiah) per penumpang;

Bagi penumpang yang divonis cacat permanen sebagian didalam jangka waktu paling lama 60 (enam puluh) hari kerja semenjak terjadi kecelakaan diberikan santunan sesuai Peraturan Menteri.

Cacat Permanen Total yang dimaksudkan pada huruf $\mathrm{c}$ angka 1 adalah hilangnya penglihatan (buta) total dari kedua mata yang tidak bisa disembuhkan, atau putusnya kedua tangan atau kedua kaki atau satu tangan dan satu kaki atau diatas pergelangan tangan atau kaki, atau hilangnya penglihatan (buta) total dari hanya satu mata yang tidak bisa dipulihkan dan putusnya satu tangan atau kaki atau pada pergelangan

Penumpang yang menderita luka-Iuka dan wajib dirawat jalan atau rawat inap dirumah sakit, atau balai pengobatan akan diberi santunan senilai penghabisan perawatan yang benar maksimum Rp. 200.000.000,00 (dua ratus juta rupiah) per penumpang

200.000.000, 00 (dua ratus juta rupiah) per penumpang

Pada Pasal 4 Peraturan Menteri Perhubungan Nomor 77 tahun 2011 juga mengatur soal apa saja yang tidak diganti rugi oleh pihak pengangkut yang dalam hal ini adala pihak maskapai penerbangan, yaitu :

Maskapai tidak memiliki tanggungjawab atas kerugian disebabkan hilangnya atau telah rusak begasi cabin, terkecuali jika penumpang bisa menunjukan bukti bahwasannya kerugian itu dikarenkan oleh maskapai atau pegawainya

Jika yang dibuktikan penumpang bisa diterima pihak maskapai atau atas dasar putusan pengadilan yang sudah berkekuatan hukum tetap (BHT) (inkracht) dikatakan telah salah, maka ganti rugi ditetapkan paling tinggi sesuai ruginya penumpang.

\section{Simpulan}

Berdasarkan uraian-uraian bab-bab tersebut maka bisa ditarik simpulan yakni:

Tugas dan Kewajiban Maskapai Penerbangan Terhadap Eksistensi Penumpang diatur di dalam Undang-Undang Republik Indonesia Nomor 1 Tahun 2009 Tentang Penerbangan dan Peraturan Menteri Perhubungan Nomor77 Tahun2011 Tentang Tanggung Jawab Maskapai Penerbangan adapun tugas dari pengangkut angkutan udara yang dalam hal ini disebut maskapai penerbangan adalah memastikan penumpang keluar dari ruang tunggu menuju ke pesawat, selama di pesawat, sampai turun di bandar udara tujuan dengan selamat tanpa ada kekurangan apapun. Selain itu memastikan bahwa barang bawaan dan bagasi penumpang juga dalam keadaan baik sampai tiba di bandar udara tujuan.

Ganti Rugi Maskapai Penerbangan Terhadap Eksistensi Penumpang diatur di dalam Peraturan Menteri Perhubungan Nomor 77 Tahun 2011 Tentang Tanggung Jawab Maskapai Penerbangan adalah sesuai dengan kesepakatan asuransi yang berisi prinsip tentang yang ditanggung akan mendapat santunan klaim dari pihak yang menanggung maksimal senilai kerugian yang diderita, pertanggungjawaban secara hukum harus dibayarkan atau kehilangan penghasilan yang diharapkan Kecelakaan pesawat atau peristiwa yang hanya sebatas ada hubungannya dengan maskapai diberikan santunan senilai $\mathrm{Rp}$. 1.250.000.000,00 (satu miliar dua ratus lima puluh juta rupiah) per penumpang. Yang ditanggung membayarkan kontribusi ialah mereka yang diikat pada suatu hubungan hukum tertentu yang telah ditetapkan undang-undang, misal hubungan kerja. Apabila mereka mendapat kesusahan kecelakaan didalam bekerja atau selama penerbangan, mereka atau ahli warisnya berhak mendapat santunan dari pihak maskapai yang nominalnya sudah tertera di undang-undang, maka tujuannya maskapai menanggung asuransi sosial menurut pembentuk undang-undang ialah untuk melindungi hak masyarakat, dan mereka yangmengalami musibah diberi ganti kerugian.

\section{Daftar Pustaka}


Alim, A. (1994). Managemen Pelayaran Niaga Jaya. Jakarta: Pustaka Jaya.

Martono, H. K. (2007). Kamus Hukum dan Regulasi Penerbangan. Jakarta: Raja Grafindo Persada.

Purwosutjipto, H. M. N. (1983). Pengertian Pokok Hukum Dagang Indonesia 3 Hukum Pengangkutan. Jakarta: Djambatan.

Setijowarno, D., \& Frazila, R. B. (2001). Pengantar sistem transportasi. Semarang: Universitas Katolik Soegijapranata.

Peraturan Menteri Perhubungan Nomor 77 Tahun 2011 Tentang Tanggung Jawab Pengangkut Angkutan Udara.

Undang-Undang Dasar Negara Republik Indonesia Tahun 1945.

Undang-Undang Republik Indonesia Nomor 1 Tahun 2009 Tentang Penerbangan. 